\title{
航海時間の分布を用いた ウェザールーチングの長期的経済評価
}

\author{
正会員 小葉 武 史* 正会員 牧 野 秀 成* \\ 正会員 清 水 玄 彦* 正会員 塩 谷茂 明*
}

An Economic Evaluation on the Navigation Hours with Weather Routing

by Takeshi Koba, Member Hidenari Makino, Member

Haruhiko Shimizu, Member Shigeaki Shiotani, Member

\begin{abstract}
Summary
It is important to evaluate whether the ship can arrive on time by using the weather routing (WR hereafter) in order to discuss the impact of the use of WR against the maritime industry. Not only the reduction of the mean time of the navigation (i.e. how fast the ship can get to the destination) but also the reduction of the variance (i.e. how precise the ship can arrive) should we consider. In this research, we simulated and analyzed the large amount of navigation data, and examined the shape of the distribution of it. We demonstrated that we can decrease the variance of the navigation hours by adopting the WR. Along with the precise arrival of the ships, (i) we can reduce the delay risk against the same estimated time to arrival, (ii) we can have enough time for shipping, and (iii) we can decrease the offshore waiting time. We have evaluated these results quantitatively.
\end{abstract}

\section{1. 緒言}

ウェザールーチング (以下 WR) の利用が海運業の価值に 与える影響を議論するには、WR を利用することで、目的地 にいかに早く到着できるかだけでなく、いかに正確な時刻に 到着できるか（定時性）を評価することが重要である。

定時性の確保は以下の 3 つの理由より海運業にとって重 要である。第一に、遅延による損失を定時性の確保によって 回避できるからである。海運業は貨物の仕出地から最終目的 地までのうち海上輸送の区間を担うが、海上輸送区間の後に 到着港から最終目的地までの陸上輸送区間があることが普 通である。たとえばサンフランシスコ港では内陸部のシカゴ などの大都市に向かう鉄道輸送網が海上輸送の後に控えて

\footnotetext{
* 神戸大学海事科学部
}

原稿受理 平成 23 年 6 月 16 日
いる。鉄道輸送は気象・海象の影響を受けにくいため時間に 正確である。海運の定時性が確保されずに貨物が遅延すれば 全体的なスケジュールが乱れ、その回復には莫大なコストが 必要となる。また、到着港において、そこから内航船舶に積 み替えられたり、ミルクラン輸送が開始されたりもする。こ の場合にも貨物の遅延は全体的なスケジュールの乱れにつ ながり、回復にかかるコストは大きい。そのため遅延が回復 不可能と考えられる場合には、しばしば寄港地の省略（抜 港)さえ行われている。さらにバースや港湾設備の使用予約、 港湾労働者の賃金など、遅延によって発生する費用は多岐に わたる。第二に、遅延を回避するために非効率な操船が行わ れる可能性があり、定時性の確保はそのような非効率操船の 必要をなくすことになるからである。遅延が莫大な費用を発 生させることから、操船者は到着予定時刻（以下 ETA）に 遅れないような操船を心がける。そのために航海区間の初め のうちは速力を上げ、まず目的港の近傍まで早くたどり着い た後に沖まちを行う。沖まちも含めた燃料消費量と速力の関 係は凸（速力の 2 乗に概ね比例）であるから、このような航 海行動は燃料消費量の点から見て非効率である。第三に、莫 大な費用を発生させる延着は当然良くないが、早く着きすぎ るのもまた非効率であり、定時性の確保によりこの早着も同 
時に防ぐことができるからである。船舶が目的港の周辺海域 に ETA 前に到着した場合、港湾周辺海域において錨泊また は漂泊すること（沖まち）が一般に行われている。この沖ま ちの間も主機は止めても、発電機は回しておかなければなら ない。リーファーコンテナを積載するコンテナ船などは特に 停船中でも常に電力を消費している。よって早着したからと いって航海以外にかかる費用が節約できるわけではない。一 方で、沖まち時間を航海時間に繰り入れることで、速力を下 げて然料消費量を節約することができる。以上の理由により、 定時性の確保によって節約できるコストは多岐にわたり、定 時性の確保は海運業の価值を高めるにあたって重要な課題 であると言える。

WR は気象・海象を予測し、船舶の耐航性を考慮して航路 を選定する気象航法である。WRの利用は定時性の確保をも たらす可能性がある。なぜなら、気象・海象こそが定時性を 損ねる攪乱要因だからである。WRによって荒天海域を回避 することで不確実性が減少し、定時性が確保される可能性は 大きい。しかし、これまでの WR に関する研究では、筆者 の知る限り定時性の確保という視点で検討されることが少 なかった。WR はある評価基準に対して最適な航路を選定す るが、既存研究においては主として航海の安全と経済運航を

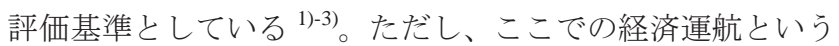
のは燃料消費量の多寡によって測られている場合が多く、定 時性の確保によってもたらされる海運業の価值の高まりに ついて論じたものではない。既存研究において定時性への言 及が少ない一つの理由は、定時性を評価するためには比較的 大量の航海時間データが必要となるからであろう。定時性は 航海時間データの分布形状（特に分散）によって測られる。 航海時間がどの程度短縮されるかを議論する場合に比べて、 航海時間の分布を議論する場合には、分布を描くに十分な量 のデータが必要となる。このような大量のデータを収集する には実船実験によっては長期間の観測を必要とし、シミュレ ーション実験によってさえ計算時間がかかる作業となる。し かし、海運業にとっての定時性確保の重要性を考慮するなら ば、WR 利用の効果を一回限りまたはごく少数の航海につい て評価するのではなく、大量のデータを用いて航海時間の分 布を評価する意義は極めて大きい。

そこで本研究では、独自に高速な WR シミュレータを作 成し、WR を用いる場合と用いない場合について、大量の航 海時間データを生成して分析することにした。本研究の目的 から、WR シミュレータには船体運動についての㛜密さを多 少犠牲にしても、大量の航海時間データを発生させることが 求められる。独自に作成した WR シミュレータはこの要請 に応えるものである。本研究はまた WR シミュレータが生
成した航海時間データの分布の形状を検討し、WRの利用に よって航海時間の分散が低下することを明らかにする。これ は WR の利用が定時性の確保につながるという予想に整合 的な結果である。さらに得られた航海時間の分布を用い、定 時性が確保されることによって、(1)一定の ETA に対する延 着危険率が低下寸ること、(2)航海に余裕時間が発生するこ と、(3)沖まち時間が短縮されることを示す。これらはす心゙ てシミュレーション結果を用いて定量的に評価される。

\section{WR シミュレータの概要}

本研究の分析に用いる航海時間のデータを生成するため、 独自に WR シミュレータを作成した。本節では、シミュレ ータを構成する(1)船体応答モデル、(2)気象・海象データ、 (3)航路最適化手法、(4)航路評価手法、について順にその概 要を説明する。

\section{1 船体応答モデル}

船体応答モデルとして高嶋他 ${ }^{1)}$ の推計式を用いた。高嶋他 の推計式は 1996 年当時に北太平洋航路に就航していたコン テナ船の実測データを用い、気象・海象に対する船体応答の パラメータを推計したものである。対象コンテナ船は、総卜 ン数 41、442 トン、全長 $247.85 \mathrm{~m}$ で、32、700PS のディーゼ ルエンジンを 1 基搭載している。

高嶋他の推計式は実船のアブログデータを統計処理する ことによって推計されたものであり、物理モデルからの積み 上げが行われたわけではない。高嶋他の方法は基本的には船 速低下量を風向と有義波高に回帰するものであるが、ここで 考慮されている説明変数は RIOS（The Research Incentive on Oceangoing Ships) 等の標準的な船体運動シミュレータの入 力変数と比較して少ない。考慮されない変数によって説明さ れる部分は誤差に含まれることになる。よって考慮する変数 が少ない分だけ、アブログデータからの推計によって得られ るモデルは比較的大きな誤差を含むことになる。しかし、こ のモデルのシンプルさは、短時間で大量の航海時間データを 発生させるという本研究のシミュレータに求められる性能 には適している。高嶋他の推計式は、プロペラ回転数、風向 および有義波高を入力変数として、船速、エンジントルク、 燃料消費量および船首部上下加速度を出力する。

\section{2 気象・海象データ}

高嶋他の推計式において必要とされる気象・海象データは 風向および有義波高である。これらのデータとして、本研究 では NCEP (アメリカ国立環境予測センター) の WW3 (Wave 
Watch 3）プロジェクトのデータを用いた。気象・海象デー 夕の解像度は経度方向 1.25 度、緯度方向 1 度である。シミ ユレーション中の気象・海象データの更新頻度は 1 日 1 回と した。またこれに合わせてシミュレーション中の船舶の針路 変更回数も 1 日 1 回としている。新たな外乱が生じない限り 針路変更の必要は生じないからである。デー夕は予報值では なく実測值を用いた。このことは将来通過するかも知れない 海域の気象・海象について操船者が事前に正確な情報を持っ ていること意味する。過去の観察期間における気象・海象デ 一タを持つ実験者には可能であるが、現実の操船者にとって は将来を完全予見していることになり非現実的である。本研 究がこの仮定をおくのは大量の航海データを発生させるた めにシミュレータの速度を上げる必要からである。将来通過 する海域についての予報が正確でなく、実現した気象・海象 に応じて航路最適化をやり直す場合に発生する計算量の増 大を避けるためにこの仮定をおいた。仮に気象・海象の予測 精度が高く、予報と実現值が変わらないのであれば選択され る航路は一致するが、もちろん現状において誤差は存在して いる。この点に関連して、最適航路の確率的評価法に関する 一連の研究 4)-6)では、気象・海象の予測值が含む誤差を、航 海時間および然料消費量の標準偏差へと写像する方法が提 示されている。これらの研究を応用して本研究を補完するこ とで、より現実的な航海時間の分布を得ることができるだろ う。

\section{3 航路最適化手法}

航路最適化手法として等時間曲線法を用いる。等時間曲線 法では、ある出発地点から針路を変えつつ一定時間内に気 象・海象の影響を考慮して到達可能な地点の集合 (外側境界 =等時間曲線）を求め、目的地に最短時間で到着する航路を 決定する。静水中であるならば等時間曲線は目的地を中心と する（地球表面上の）円周となる。しかし実際には気象・海 象の影響を受けるために円周は歪む。この歪んだ円周の中か ら目的地に最も近い点を選び出すことで船舶の針路を定め る。

\section{4 航路評価手法}

本研究では航海時間の分布の形状、特に分散を評価する。 それに加えて高嶋他の推計式より燃料消費量、船首部上下加 速度、エンジントルクが得られるのでそれらも航路の評価に 活用する。高嶋他に従い、船首部上下加速度が $0.8 \mathrm{G}$ を超え る確率が $0.1 \%$ を超える場合を閾值とし、それを超える回数 を航海ごとにカウントした。またエンジントルクについても 実際の対象船舶でエンジン負荷を軽減するために燃料ガバ
ナが作動するトルクの值を閾值とし、それを超える回数を航 海ごとにカウントした。これら航海の安全性に関する指標を、 以下ではそれぞれピッチ危険度、トルク危険度と表現する。

以上の性質をもつ WR シミュレータを Matlab を用いてコ 一ディングした。航海データを生成させるため、北太平洋航 路（野島崎沖・サンフランシスコ沖、大圈距離約 4500NM） をプロペラ回転数一定 $(72 \mathrm{rpm})$ で往復させた。プロペラ回 転数を一定としていることより、最適化のための制御変数は 針路のみである。すでに述べたように気象・海象データの更 新間隔および針路変更の間隔は 1 日 1 回である。気象・海象 データの期間は季節変動をならすために 1 年分（2009 年 1 月 1 日から同年 12 月 31 日まで）を用いた。対象船舶は毎日 グリニッジ標準時午前 0 時に出港するものとして、東航西航 それぞれ 365 航海分、合計 730 航海分のデータを生成した。 それぞれの航海は WR を用いる場合と用いない場合（大圏 航路）の二種類をシミュレートしているので、最終的に分析 で用いるサンプルサイズは 1460 となった。

\section{3. シミュレーション結果}

\section{1 航海時間の分散の低下}

シミュレーションの結果を Table 1 にまとめる。平均航海 時間は 210 時間程度（8 日から 9 日）であり、実船舶の北大 西洋航路における航海時間と整合的である。平均速力は 20 ノット強であった。然料消費量は 700 トンから 730 トン程度 である。北大西洋航路では東航よりも西航のほうが航海時間 と然料消費量が大きい。これは大気および海流の大循環が影 響していると考えられる。

航海時間の変化について、WR を利用するか否かにかかわ らず、平均航海時間の変化は大きくはない（東航で WR の 利用によって平均航海時間が 208.1 時間から 208.3 時間へと わずかながら伸びているが、WR は最短時間航法であるため この結果はシミュレータ側の誤差である）。しかし、標準偏 差 (分散の正の平方根) はWR の利用により低下している。 このことは WR の利用が定時性の確保につながるという予 想に整合的である。また WR の利用により然料消費量が減 少する。特に西航においては一航海あたり 729 トンから 722 トンへと約 7 トンの燃料が節約される。これは一航海あたり の全燃料消費量の $1 \%$ 弱にあたる。西航が東航に比べて WR を利用する効果が大きいのは西航の場合に向かい風あるい は向かい波中を航海することが多いからと考えられる。燃料 消費量の分散も WR の利用によって低下寸る。安全性につ いても、ピッチ危険とトルク危険の両方の指標で WR の利 
用による改善が見られた。これは荒天海域を回避して航海す るからである。

Table 1 Results of simulation.

\begin{tabular}{|c|c|c|c|c|c|}
\hline & \multicolumn{2}{|c|}{ "経済性指標 } & \multicolumn{3}{|c|}{ 安全性指標 } \\
\hline WR & 航海時間 [hr & 燃料消費量 [t] & ピッチ危険 & トルク危険 & $\bar{N}$ \\
\hline \multirow{3}{*}{$\begin{array}{c}\text { OFF } \\
\text { 東航 } \\
{ }^{0 N}\end{array}$} & 208.139 & 707.914 & 0.307 & 0.082 & \\
\hline & (1. 990) & (11. 721) & (1. 652) & $(0.740)$ & \\
\hline & $\begin{array}{l}208.319 \\
(1.587)\end{array}$ & $\begin{array}{l}7.313 \\
106)\end{array}$ & $\begin{array}{c}0.129 \\
(0.743)\end{array}$ & $\begin{array}{c}0.012 \\
(0.128)\end{array}$ & 365 \\
\hline \multirow{2}{*}{$\begin{array}{c}\text { OFF } \\
\text { 西航 } \\
\text { ON }\end{array}$} & $\begin{array}{l}211.541 \\
(3.675)\end{array}$ & $\begin{array}{l}728.643 \\
(23.120)\end{array}$ & $\begin{array}{c}2.912 \\
(5.824)\end{array}$ & $\begin{array}{c}1.126 \\
\text { (3. 223) }\end{array}$ & 365 \\
\hline & $\begin{array}{c}210.868 \\
(2.959)\end{array}$ & $\begin{array}{l}721.897 \\
(17.840)\end{array}$ & $\begin{array}{c}0.762 \\
(2.456)\end{array}$ & $\begin{array}{c}0.101 \\
(0.568)\end{array}$ & 36 \\
\hline
\end{tabular}

）内は標集偏差。
ピッチ危険とは船首上下加速度が $0.8 \mathrm{G}$ を超える確率が $0.1 \%$ 超えた回数。 トルク危険とは燃料ガバナが作動した回数。

次に、航海時間の分布を見よう。得られた航海時間のデー タはヒストグラムを描くことにより、おおよその分布の傾向 を把握することができる。しかし、本稿の目的である統計的 評価を行う場合には、離散型のグラフではなく連続型の確率 密度を用いることが望ましい。航海時間の分布については先 験的にいかなる分布が当てはまるのかが明らかではないの で適当な既知の分布を当てはめてそのパラメータを推計す ることは難しい。このような場合、分布を特定化しないノン パラメトリック推定を行うことが考えられる。カーネル平滑 化密度推計はそのような場合に利用される代表的手法であ る。カーネルには一般的なガウス型カーネルを採用した。

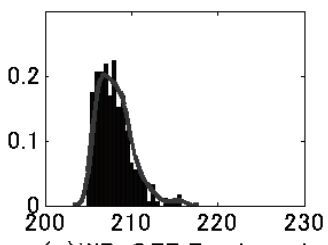

(a) WR-OFF Eastbound

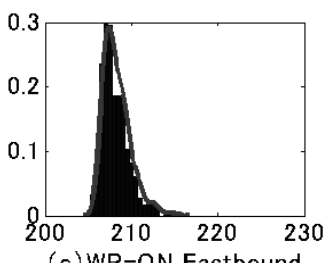

(c) WR-ON Eastbound

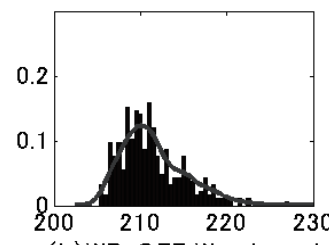

(b) WR-OFF Westbound

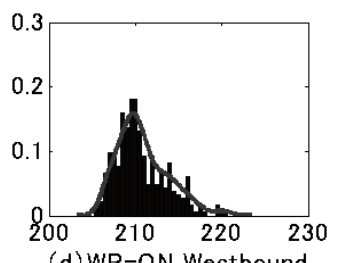

(d) WR-ON Westbound
Fig.1 Distribution of navigation hours.

航海時間の分布をヒストグラムとカーネル平滑化密度関 数で表したものが Fig.1 である。Fig.1 のパネル(a)(b)は WR を利用しない場合の東航・西航の航海時間の分布をそれぞれ 表す。横軸は航海時間、縦軸は度数あるいは確率密度である。 パネル(c)(d)は WR を利用した場合の東航・西航の航海時間 の分布をそれぞれ表す。東航・西航ともにWR を利用した 場合に航海時間の分布が最頻值周りに集中している。すなわ
ち Table 1 で確認したように分散が小さくなっており、定時 性が改善されていることがわかる。

航海時間の分散が低下し、定時性が確保されることによっ て、(1)延着危険率の減少、(2)余裕時間の発生、(3)沖まち時 間の短縮が期待される。以下では推計されたカーネル密度関 数を用い、この 3 点を定量的に評価しよう。

\section{2 延着危険率の低下}

WR を用いることで定時性に改善が見られることがわか つた。このことから WR を用いることで ETA を含む他の条 件を一定として延着の危険が減少することが予想される。 Fig.2 はこのことを説明するための模式図である。Fig.1 と同 じく横軸は航海時間、縦軸は確率密度である。Fig.1 で見た ように WR を用いた場合の航海時間の分布は、用いない場 合よりも分散が小さく、最頻值周りに分布が集中している。 一定のETAに対して延着する危険率はETAよりも右側の密 度関数の積分によって求めることができる。Fig.2 より明ら かなように、WR を用いた場合の延着危険率は、用いない場 合よりも小さい。

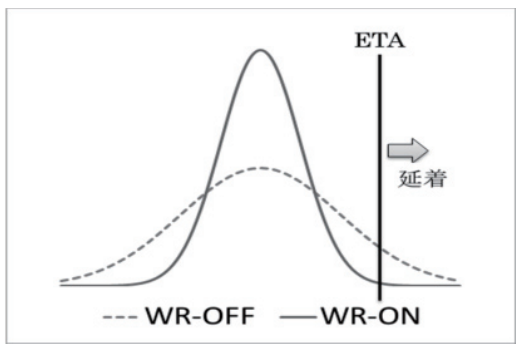

Fig.2 Reduction of delay risk

Fig.1 で求めたカーネル密度関数を用いて、WR の利用に よって延着危険率がどの程度低下するかを具体的に計算し た結果を Table 2 にまよる。たとえば当初（WR を利用し ない場合において）10\%の延着が許容されていたとしよう （これは製造業における許容可能な不良品率にあたる）。こ のとき WR の利用により定時性が改善されることを通じ、 ETA を一定として、延着危険率が 10\%から東航で 8.0\%、西 航で $4.2 \%$ へ低下寸る。元々延着危険率が $1 \%$ しか許容され ていない場合には、WR を利用することで西航での延着危険 率は $0.008 \%$ で低下し、無視できるほど小さくなる。

Table 2 Delay risk

\begin{tabular}{cc|ccc}
\hline \hline \multicolumn{2}{c|}{ 延着危険率 $($ WR-OFF) } & $10.000 \%$ & $5.000 \%$ & $1.000 \%$ \\
\hline \multirow{2}{*}{ 東航 } & WR-ON & $7.997 \%$ & $3.560 \%$ & $0.204 \%$ \\
& 変化分 & $\boldsymbol{\Delta} 2.003 \%$ & $\boldsymbol{\Delta} 1.440 \%$ & $\boldsymbol{\Delta} 0.796 \%$ \\
\hline \multirow{2}{*}{ 西航 } & WR-ON & $4.222 \%$ & $1.681 \%$ & $0.008 \%$ \\
& 変化分 & $\boldsymbol{\Delta} 5.778 \%$ & $\boldsymbol{\Delta} 3.319 \%$ & $\boldsymbol{\Delta} 0.992 \%$ \\
\hline
\end{tabular}




\section{3 余裕時間の発生}

次に、許容可能な延着危険率を一定として、WR を利用す ることで航海時間にどれだけの余裕が発生するかを考える。 Fig.3 において、WR を利用する場合と利用しない場合のそ れぞれについて、許容可能な延着危険率を一定とするように それぞれ ETA を定める。つまり WR を利用する場合と利用 しない場合の密度関数より下側で ETAより右側の面積がそ れぞれ等しくなるように ETA を定める。このとき WR を利 用しない場合の ETA は利用する場合よりも右側にある。な ぜなら WR を利用しない場合には延着する危険が大きいか ら、許容可能な延着危険率を固定するならば、より長い航海 時間が確保される必要があるからである。WR を利用するこ とにより定時性が改善されるから WR を利用しないときほ どの航海時間は必要とされない。そこから余裕時間が生まれ る。余裕時間は 2 つの ETA の差として計算することができ る。

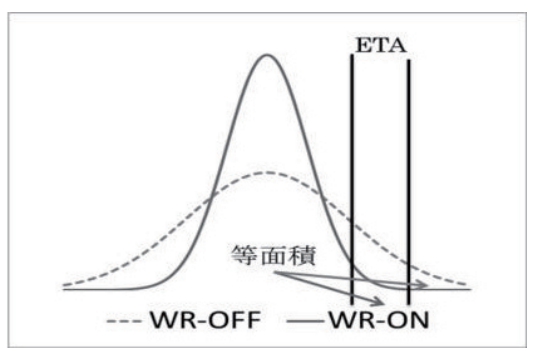

Fig.3 Generating the allowance of delay

Table 3 Allowances of delay

\begin{tabular}{|c|c|c|c|c|}
\hline \multicolumn{2}{|c|}{ 延着危険率 } & $10 \%$ & $5 \%$ & $1 \%$ \\
\hline \multirow{4}{*}{ 東航 } & WR-OFF $(x)$ & 210.851 & 212.025 & 215.254 \\
\hline & WR-ON (y) & 210.517 & 211.505 & 213.605 \\
\hline & 余裕時間 $(t=x-y)[h r s]$ & 0.334 & 0.520 & 1.649 \\
\hline & 余裕時間[min] & 20 & 31 & 99 \\
\hline \multirow{4}{*}{ 西航 } & WR-OFF (x) & 217.095 & 219.057 & 222.703 \\
\hline & WR-ON (y) & 215.292 & 216.715 & 219.967 \\
\hline & 余裕時間 $(t=x-y)[h r s]$ & 1.803 & 2.342 & 2.736 \\
\hline & 余裕時間[min] & 108 & 141 & 164 \\
\hline
\end{tabular}

Table 3 は余裕時間の計算結果をまとめたものである。 元々の許容される延着危険率が $1 \%$ あ゙り西航で WR を利用 する場合には、延着危険率を変化させることなく 164 分 $(2$ 時間 44 分）の余裕時間が発生する。発生した余裕時間を航 海時間に繰り入れることで、速力を下げることができ、さら なる燃料消費量の節約が期待できる。

\section{4 沖まち時間の減少}

次に WR による定時性の改善により沖まち時間の減少が 期待できることを示す。WRを用いることで延着する船舶の 割合が小さくなることはすでに見た。ここでは大幅に早着す
る船舶の割合も小さくなりそのことが平均沖まち時間の削 減につながることを見る。

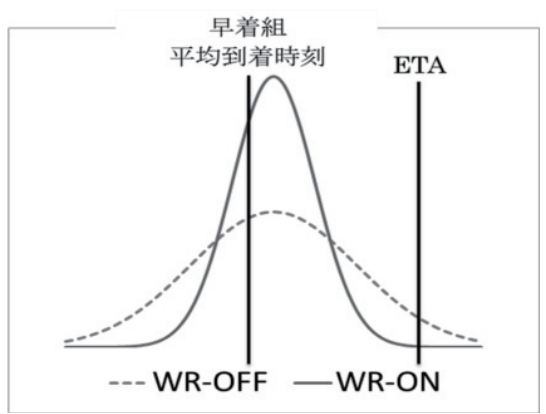

Fig.4 Reduction of offshore waiting time

Fig.4において、許容可能な延着危険率を固定して ETA を 定め、ETA よりも左側の船舶に注目する。これらの船舶は ETA 前に到着した早着組である。密度関数よりこれら早着 組の船舶の平均到着時刻を求めることができる。この早着組 平均到着時刻と ETA との差を平均沖まち時間と定義する。 WR を利用する場合と利用しない場合についてそれぞれ平 均沖まち時間を求めた結果を Table 4 にまとめた。

Table 4 Offshore waiting time

\begin{tabular}{|c|c|c|c|c|c|}
\hline \multicolumn{3}{|c|}{ 遅延危険率 } & $10 \%$ & $5 \%$ & $1 \%$ \\
\hline \multirow{7}{*}{ 東航 } & WR-OFF & 閾値 (ETA) & 210.851 & 212.025 & 215.254 \\
\hline & & 早着組航海時間 & 207.649 & 207.849 & 208.065 \\
\hline & & 平均沖まち時間 & 3.202 & 4.176 & 7.189 \\
\hline & WR-ON & 閾値 (ETA) & 210.517 & 211.505 & 213.605 \\
\hline & & 早着組航海時間 & 207.930 & 208.088 & 208.256 \\
\hline & & 平均沖まち時間 & 2.587 & 3.417 & 5.349 \\
\hline & & 変化分[hrs] & $\Delta 0.615$ & $\Delta \quad 0.759$ & A 1.841 \\
\hline \multirow{7}{*}{ 西航 } & WR-OFF & 闇値 (ETA) & 217.095 & 219.057 & 222.703 \\
\hline & & 早着組航海時間 & 210.676 & 211.060 & 211.414 \\
\hline & & 平均沖まち時間 & 6.419 & 7.997 & 11.289 \\
\hline & WR-ON & 閾値 (ETA) & 215.292 & 216.715 & 219.967 \\
\hline & & 早着組航海時間 & 210.165 & 210.472 & 210.766 \\
\hline & & 平均沖まち時間 & 5.127 & 6.243 & 9.202 \\
\hline & & 変化分[hrs] & $\Delta 1.292$ & A 1.754 & $\Delta 2.087$ \\
\hline
\end{tabular}

Table 3 で見たように、東航で WR を用いない場合に延着 危険率を 10\%以下にするためには 211 時間の航海時間が確 保されなければならない。この值を用いて出発時刻より起算 して 211 時間先を ETA としよう。ETA 前に早着する船舶(割 合は当然 90\%）の平均航海時間を密度関数より求めると約 208 時間であった。ETA との差である平均約 3 時間は目的港 の近傍で沖まちをして過ごすことになる。WRを用いること で延着する船舶が減少すると同時に大幅に早着する船舶も 減少する。このため WR を利用した場合の平均沖まち時間 は約 2 時間半へと減少する。西航で延着危険率を $1 \%$ 以下と する場合には、WR を利用することで約 2 時間（125 分間） の沖まち時間を削減することができる。 


\section{4. 結 言}

本研究は WR の利用が定時性の確保をもたらし、海運業 の価值を高める可能性について議論した。WR の利用により 船舶がいかに正確な時間に到着することできるかを評価す るには、シミュレーションによって大量の航海時間データを 生成し、その分布を評価する必要がある。そこで本研究では 独自に高速な WR シミュレータを作成して大量の航海時間 データを生成し、得られたデータの統計分析を行った。

シミュレータが生成した航海時間のデータより、航海時閒 の分散が低下することが確かめられた。これは WR が攪乱 要因である荒天海域を避けた航路の選択を行うからである。 また WR を利用することで然料消費量を節約することがで き、同時に安全性も高まることがわかった。これもWR の 利用により荒天海域を回避した航海を行うことによる。本研 究のシミュレーション結果では、経済性の追求と安全性の追 求はトレードオフではない。

本稿ではさらにシミュレーションによって得られた航海 時間の分布を用いて、WRによる定時性の確保がいかなる経 路を通じて海運業の価值を高めるかについて検討し、WRの 利用によって、(1)延着危険率の減少、(2)余裕時間の発生、 (3)沖まち時間の短縮が生じることを示した。延着危険率の 低下は海運業の輸送サービスとしての信頼を高める。また余 裕時間の発生は、その時間を航海に組み入れることで速力を 低下させて燃料消費量を削減できるだけでなく、操船者の気 持ちの余裕となって安全性の向上にも資することが期待さ れる。さらにWR の利用によって沖まち時間の節約も可能 である。なお、本研究において、これらの WR 利用の効果 は全て定量的に評価された。

\section{謝 辞}

本研究は、文部科学省特別研究推進「輸送の三原則を統合 した国際海上輸送システム創出の研究」の一環として行った もので、関係者の方々のご協力・ご指導に厚く御礼申し上げ ます。

\section{参 考 文 献}

1) 高嶋恭子・萩原秀樹・庄司るり：ウェザールーティン グによる燃料節約—コンテナ船の航海データを用いたシミ ユレーション、日本航海学会論文集、第111号、2004、 pp.259-266。

2) 嶋田陽一・高橋桂子・塩谷茂明 : 日本〜北米間のウェ
ザールーティングー航海時間に注目した国際ハブ港湾、日本 航海学会論文集、第 123 号、2010、pp.21-28。

3) 小葉武史・牧野秀成・嶋田陽一・石井江里子・塩谷茂 明・小林英一：ウェザールーチングにおける経済性と安全性 の両立に関する定量分析、日本船舶海洋工学会講演論文集、 K-OS4、2010。

4) ウェザー・ルーティング研究グループ: ウェザールー ティングー気象情報に基づく最適航法、成山堂書店、1992、 第 5 章。

5）萩原秀樹・庄司るり：確率的なウェザールーティング に関する研究一航海時間と燃料消費量の標準誤差の推定精 度、日本航海学会論文集、第 104 号、2001、pp.1-11。

6）高嶋恭子・加納敏幸・小林充 : 到着遅延リスクを考慮 した内航船の省エネルギー運航について、日本航海学会論文 集、第 119 号、2008、pp.145-151。 